\title{
नेपाली सेनामा समावेशिता: एक विश्लेषण
}

कमल बहादुर महत

लेखसार

आधुनिक नेपालको सबैभन्दा पुरानो संस्थाको ऐतिहासिक विरासत बोकेको नेपाली सेनाले यसको स्थापनाकालदेखि नै समावेशिताको नीतिलाई अख्तियार गरेको पाइन्छ। नेपाली सेनामा विभिन्न जातीय समूहहरु मगर, गुरुङ; तामाङ, किराती। लिम्ब र मधेशी समुदायहरुका बटालियनहरु नेपाली राज्यले आरक्षणको प्रावधान सुरु गर्नुभन्दा दशकौं अघिवाट अस्तित्वमा थियो। यसले नेपाली सेनाको चरित्र स्थापना कालदेखि नै समावेशी थियो भन्ने देखाउॅछ। २०७२ सालमा जारी नेपालको संविधानले आर्थिक, सामाजिक, राजनैतिक ₹ प्रशासनिक दृष्टिले पछाडि परेका विभिन्न लक्षित वर्गहरुलाई समानुपातिक समावेशी सिद्धान्तका आधारमा राज्यको निकायमा सहभागिता हुन पाउने हकलाई मौलिक हकको रुपमा व्यवस्था गरेको छ। त्यसै अनुरुप नेपाली सेनाले पनि आफ़नो समावेशिताको मौलिक चरित्रलाई कायम राख्दै अभौ समावेशी हुने तिर पाइला चालिरहेको पाइन्छ। सैनिक सेवा नियमावली, २०६९ ले खुल्ला प्रतियोगिताद्धारा नेपाली सेनामा पदपर्ति हुने पदहरुको पैंतालिस प्रतिशत पदसंख्या समावेशीकरणका लागि छुट्याई सो संख्यालाई शत प्रतिशत मानी महिला, आदिवासी/जनजाति, मधेशी, दलित र पिछडिएको क्षेत्रका उम्मेदवारहरु बिच कमश: विस, बत्तिस, अट्ठाइस, पन्ध्र र पाँच प्रतिशत छुट्याएर ती समूह/समुदायका उम्मेदवारहरु बिच मात्र प्रतिस्पर्धा गर्ने प्रावधान लाग गरी नेपाली सेनामा पनि
आरक्षण मार्फत प्रतिनिधित्व बढाउने प्रयास गरिएको छ। २०६२/O६३ को राजनैतिक परिवर्तनपछि राज्यका अन्य अड़हरुमा कै नेपाली सेनामा पनि समावेशी गर्नुपर्ने प्रावधानहरुले गति पायो। समावेशीकरणको नीति नेपाली राज्यका अन्य अड़हरु कैं नेपाली सेनाले पनि अड़ीकार गर्दा त्यसका राम्रा ₹ नराम्रा असरहरु नेपाली सेनाले पनि भोगिरहेको छ। द्वितीयक स्रोतका तथ्याकंहरुको विश्लेषणका आधारमा नेपाली सेनामा समावेशिताको विगतदेखि हालसम्मको अवस्था विश्लेषण गर्दे आगामी दिनमा पनि नेपाली सेनाले आफ्नो समावेशी चरित्र मार्फत् नेपाल राष्ट्र/राज्यको सार्वभौमसत्ता, अखण्डतालाई कसरी जोगाई राख्न सक्छ भन्ने विश्लेषण यो लेखमा समेटिएको छ।

शब्द कुज्जी : नेपाली सेना, समावेशिता, राष्ट्र-राज्य, संरचना, आरक्षण ।

\section{परिचय}

यो अनुसन्धान मूलतः नेपाली सेनामा समावेशीकरणमा केन्द्रित रहेको छ। यसका लागि समावेशीकरणको वर्तमान अवस्थाबारे उपलब्ध तथ्याकंहरुका आधारमा अन्य राज्यका अड्नहरु कैं खासगरी २०६२/०६३ को राजनैतिक परिवर्तनपछि, आएको 'समावेशीकरण' को लहरले नेपाली सेनामा के कस्तो अवस्थाको सिर्जना गरेको छ ? भनी यस लेखमा विश्लेषण गरिएको छ। 


\section{समावेशीकरण सम्बन्धी मान्यताहरु}

२०७२ सालमा जारी नेपालको संविधानको प्रस्तावनामा सामाजिक न्याय सुनिश्चित गर्न समानुपातिक समावेशी र सहभागितामलक सिद्धान्तका आधारमा समतामूलक समाजको निर्माण गर्ने संकल्प गरिएको छ (नेपालको संविधान, २०७२, पृ.१)। त्यस्तै संविधानको धारा ४२ मा मौलिक हक अन्तरगत सामाजिक न्यायको हकमा सामाजिक रूपले पछाडि परेका महिला, दलित, आदिवासी, आदिवासी जनजाति, मधेशी, थारू, अल्पसंख्यक, अपाङगता भएका व्यक्ति, सीमान्तीकृत, मुसलमान, पिछडा वर्ग, लैंगिक तथा यौनिक अल्पसंख्यक, युवा, किसान, श्रमिक, उत्पीडित वा पिछडिएको क्षेत्रका नागरिक तथा आर्थिक रूपले विपन्न खस आर्यलाई समानुपातिक समावेशी सिद्धान्तका आधारमा राज्यको निकायमा सहभागिताको हक हुनेछ भनी प्रावधान राखिएको छ (नेपालको संविधान, २०७२, पृ.१७-१६)। नेपालको संविधानकै धारा पू मा राष्ट्रिय एकता र राष्ट्रिय सुरक्षा सम्बन्धी नीति अन्तरगत राष्ट्रिय सुरक्षा नीतिका आधारमा नेपाली सेनालाई समावेशी बनाउने उल्लेख छ। समावेशीकरणलाई मुलुकको शान्ति, स्थायित्व र दिगो विकासको आधारको रूपमा पनि लिएको पाइन्छ। नेपालको संविधान बमोजिम संघ, प्रदेश र स्थानीय तहले राज्यशक्तिको प्रयोग गर्ने हुनाले समावेशिता कार्यान्वनमा समेत यी तिनै तहको भूमिका उल्लेखनीय हुने देखिन्छ (राष्ट्रिय समावेशी आयोग, २०७७, प.१-२)। संविधानमा यस्तो व्यवस्था हुॅदाहुँदै साथै प्रत्येक दश वर्षमा आरक्षणको प्रावधानबारे पुन: मूल्याकंन गर्ने भनिएतापनि आरक्षणबाट तत् तत् वर्गका अधिकांश: 'सम्पन्न' वर्गले मात्र लाभ लिइरहेको पाइन्छ।

पृथ्वीनारायण शाहले नेपालको विविधतालाई सम्मान र उच्च प्राथमिकता दिदैं नेपालको तत्कालीन भक्षेत्रभित्र सनातनदेखि प्रचलनमा रहेका धार्मिक-सांस्कृतिक परम्पराहरू जस्तै धामी, भाँकी, मस्टो, गुरूवा, लामा, भिक्षु, पन्थ आदि जुन पहिला इस्लाम र पछि, क्रिश्चियन
प्रभावबाट मुक्त रही मौलिक पहिचान कायम राखन सफल भई आएका थिए त्यसलाई जोगाएका थिए (शाह, २०६४, पृ. २६)। उनले नेवारहरूको नाच भिकाई हेरे गरी नेपाली संस्कृति, मौलिक पहिचान, विविधता, धनराशीलाई बचाउने 'दिव्य उपदेश' दिएको थिए (Nepal Law Commission, 2021)। समावेशीकरण भनेको प्रत्येक व्यक्तिलाई पर्ण रुपमा समावेश हुन र योगदान दिन पूर्ण रुपमा अवसर दिइन्छ (Miller as cited in Munshi, 2019, p. 9)। त्यस्तै, समावेशीकरण एउटा संस्कृति हो जसले प्रत्येक कामदारलाई संगठनसॅग जोड्छ, यसका साथै यसले एकता, लचकता र निष्पक्षतालाई बढावा दिन्छ। यसले विविधतालाई पूरै सङगठनमा फैलाऊछ जसले संगठनका प्रत्येक सदस्यलाई सडगठठनको लक्ष्य प्राप्तिका लागि पूर्ण क्षमताका साथ सहभागी हुन प्रोत्साहित गर्दछ (Executive Order No. 13583, 2011, p. 5) । त्यस्तै सामाजिक समावेशीकरणको परिभाषा दिदैं समाजशास्त्री हिलारी सिल्भरले यो बहुआयामिक, सामाजिक सहभागिताका अवसरहरू बढाउने प्रकिया, समाजले निर्धारण गरेका सामाजिक भमिका निर्वाह गर्ने क्षमता बढाउने, समाजमा बाँधिन आदर र पहिचान फराकिलो पार्ने, सामाजिक एकता, सद्भाव बढाउने प्रकियाका रूपमा अर्थ्याएकी छन् (Silver: 2015, p. 2-3)। अभ उनले त सामाजिक समावेशीकरणले विभिन्न व्यक्तिहरु बिच अन्तरक्या बढाउने गर्दछ भनी उल्लेख गरेकी छन् (Silver: 2015, p. 3) । संयुक्त राष्ट्र संघद्धारा सन् २०१६ देखि सन् २०३० सम्म तय गरिएको सहस्राब्दी विकास लक्ष्यहरुमध्ये लक्ष्यहरु ऽ, १०, ११, र १६ समावेशीकरणसँग सम्बन्धित छन् । त्यस्तै लक्ष्य $\zeta$ ले दिगो, समावेशी र दिगो बृद्धिका साथै रोजगारी सिर्जनालाई प्रवर्द्धन गर्दछ। त्यस्तै लक्ष्य १० ले उमेर लिड्ग, अपाझ्गता, जात, जाति, उत्पति, धर्म, आर्थिक वा अन्य अवस्थाका आधारमा भेदभाव नगरी सशक्तिकरण गर्नुका साथै सबैको सामाजिक, आर्थिक र राजनैतिक क्षेत्रमा समावेशीकरण प्रवर्द्धन गर्न जोड दिन्छ (Silver: 2015,p. 1) । त्यस्तै सहस्राब्दी विकास 
लक्ष्यको लक्ष्य १६ ले शान्त र समावेशी समाजको साथै संस्थाहरुमा समावेशिताको लागि जोड दिन्छ, (Silver: 2015 P. 1)। नेपालमा समावेशीकरणको राजनीति निश्चित उद्देश्यबाट प्रेरित भएको देखिन्छ, जसले स्वदेशी र विदेशी स्वार्थहरूलाई धेरै हदसम्म पूर्ति गर्न सघाउ पुच्याएको पाइन्छ। यसले विपन्न, गरिब, सीमान्तीकृतहरूलाई मूलधारमा ल्याउनुको सट्टा राज्यलाई कमजोर बनाउने अनि तत् तत् समूह, वर्गभित्रका सम्भ्रान्तहरूलाई कन् अवसर दिने औजारका रूपमा धेरै मात्रामा प्रयोग भएको देखिन्छ, (राष्ट्रिय समावेशी आयोग, २०७७, प्.१५)।

निजामती सेवा र आरक्षणसँग सम्बन्धित विद्यमान् कानुनमा आर्थिक तथा सामाजिक रुपमा पछाडि परेका महिला, आदिवासी / जनजाति, मधेशी, दलित, पिछडिएको क्षेत्रका व्यक्ति, अपाइ्गता भएका व्यक्तिहरुको विवरण नेपाल सरकारले नेपाल राजपत्रमा सूचना प्रकाशन गरी नतोकेसम्मका लागि ती वर्ग, समुदायभित्रका सम्पूर्ण नागरिकहरुले 'ब्लान्केट' पद्धति अनुरुप अवसर पाउने वर्तमान पद्धतिले ती वर्ग/समूह भित्रका 'सम्भ्रान्त' हरुले मात्र लाभ लिई आरक्षणको मर्म माथि नै प्रहार गरेको पाइन्छ (राष्ट्रिय समावेशी आयोग, २०७२, प्. १५)। सुरुमा त सामाजिक समावेशीकरण भित्र प्रचलित सामाजिक बहिष्करण शब्दले 'रिपब्लिकन' अर्थ बोक्यो तर पछि, यो विभिन्न देशहरुमा फैलिदै जाँदा ती देशहरुले अँगाल्ने 'सेटिड्ग' अनुसार यसको अर्थ फरक हुन थाल्यो (Silver: 2015, p. 3)। नेपालमा पनि विक्रम संवत् २०६२/०६३ को राजनैतिक परिवर्तनपछि, यसले त्यो बेलामा केन्द्रीय राजनीति, नीति निर्माणमा प्रभाव पार्ने वर्ग, तप्काहरूले समावेशीकरणलाई आआफनो 'स्वार्थ', 'फाइदा' का लागि धेरै हदसम्म प्रयोग गरेको देखिन्छ। अभ यसले त 'फुटाऊ र राज गर' भन्ने औपनिवेशिक औजारको पनि काम गरेको पाइन्छ।

नत्र त नेपाली सेना लगायत राज्य गैर राज्यका संरचनाहरुमा हामीले आरक्षण मार्फत् तत् तत् वर्गका ‘विपन्न' तर प्रतिभाशाली व्यक्तिहरुको राज्य गैर राज्य
संरचनाहरुमा प्रवेश पाउने यो एकदशक भन्दा बढीको आरक्षणको अभ्यासलाई नियाल्दा सो आरक्षण गरिएका समूहहरु महिला, आदिवासी जनजाति, मधेशी, दलित, अपाइ्ग, पिछडिएको क्षेत्र, मुसलमान लगायतबाट अधिकांशतः 'पहुँच' वाला वर्ग, सम्पन्न व्यक्ति र वर्गले प्रवेश पाएको देखिन्छ, नेपालमा समावेशीकरणसम्बन्धी भएको एक अध्ययनले पहाडे ब्राम्हण, नेवार र मधेशी ब्राम्हण/क्षत्री समूहहरु सेवा, भौतिक पूर्वाधार र राजनीतिका सम्पूर्ण सूचकाड्कहरुमा सबैभन्दा ज्यादा समावेश भएका देखिन्छन् भने मधेशी दलित, पहाडी दलित र मुसलमानहरु सबैभन्दा कम समावेश भएका देखिन्छन् (Central Department of Sociology and Anthropology: 2014, p. xxxii) .

सर्वेक्षण गरिएका जनसंख्यामध्ये सरकारी जागिरमा मधेशी बाहुन क्षेत्री सबैभन्दा ज्यादा २९.१ प्रतिशत, नेवार २६.३ प्रतिशत, पहाडे क्षेत्री २१.५ प्रतिशत, पहाडे ब्राम्हण १५.द प्रतिशतले पहुँच पाएको देखिन्छ (Central Department of Sociology and Anthropology: 2014, p. xxxii)। सोही सर्वेक्षणले नै सर्वेक्षण गरिएका जनसंख्या मध्ये साक्षरता दर मधेशी बाहुन क्षेत्रीको ९१ प्रतिशत, पहाडे ब्राम्हण द६ प्रतिशत, नेवार ५४ प्रतिशत, पहाडे क्षेत्री ५० प्रतिशत देखाएको पाइन्छ, जसमा मधेशी दलितको सबैभन्दा कम साक्षरता दर ४९.१ प्रतिशत मात्र पाइएको छ (Central Department of Sociology and Anthropology: 2014, p. 42) । यस सर्वेक्षणमा अध्ययन गरिएका ९६ वटा सामाजिक समूहहरूमध्ये जैन, मारवाडी र कायस्थ समूहहरूको साक्षरता दर सबैभन्दा उच्च भण्डै एक सय प्रतिशत ( ९७-९६ प्रतिशत) पाइएको थियो जसमध्ये वानियॉ, व्यासी ९३ प्रतिशत र राजपुत ९१ प्रतिशत पाइएको थियो। त्यस्तै, सो अध्ययनमा समेटिएका समूहहरूमध्ये सबैभन्दा न्यून साक्षरता दर मुसहर मात्र २० प्रतिशत पाइएको थियो (Central Department of Sociology and Anthropology: 2014, p. 42) । त्यस्तै, सो अध्ययनले पुरुषको साक्षरता दर ५७ प्रतिशत र महिलाको साक्षरता दर ६७ प्रतिशत 
पाएको छ (Central Department of Sociology and Anthropology: 2014, p. 43)।

नेपालमा पछिल्लो समय भएका अध्ययनहरूमा जानीजानी ब्राम्हण क्षेत्री समूहहरूलाई एकै ठाउॅमा राखेर तथ्याक सङ्ककलन, विश्लेषण गर्ने अभ कतिपय अध्ययनमा त ब्राम्हण, क्षेत्री र नेवार समूहहरूलाई एकै ठाउँमा राखेर समावेशी लगायतको तथ्याक विश्लेषण गरेको पाईन्छ जसले जनसंख्याको सबैभन्दा ज्यादा प्रतिशतमा रहेको क्षेत्री समुदायलाई अन्याय भएको ।

वर्तमान संविधानले स्थानीय सरकारको अधिकार सूची अन्तर्गत अनुसूची द मा स्थानीय तथ्याक र अभिलेख सड्कलनको जिम्मा स्थानीय सरकारलाई दिएकाले स्थानीय सरकारले नै विश्वसनीय रूपमा वैज्ञानिक तवरले विपन्नहरूको खण्डीकृत तथ्याकं व्यवस्थित रूपमा राखेमा हालको 'सम्भ्रान्त' व्यक्तिहरुले आरक्षणका नाममा लिइरहेको सुविधालाई वास्तविक विपन्न वर्गसम्म पुच्याउन सकिने देखिन्छ, (नेपालको संविधान, २०७२, प्.१७६)। साथै नेपाली सेना बाहेक अन्य राज्यका अड्नहरू न्यायपालिका, कार्यपालिका, व्यवस्थापिका, प्रशासनतन्त्र, विश्वविद्यालय, सार्वजनिक संस्थान, निजी क्षेत्र, व्यवसाय, उद्यम, पत्रकारिता, गैर सरकारी संस्था, नागरिक समाज लगायतमा ब्राम्हण र नेवार समुदायको तुलनामा क्षेत्रीहरुको न्यून उपस्थिति रहेको पाइन्छ। साक्षरता दरले निकै नेपाली सेना लगायत राज्यको संरचनामा प्रवेश गर्न पक्कै पनि बाधा पुयाउँछ। प्रतिस्पर्धात्मक परीक्षा हुने नेपाली सेना लगायत राज्य र गैर राज्यका संरचनाहरूमा उपस्थिति जनाउन गुणस्तरीय शिक्षाको ठूलो भूमिका हुन्छ।

जातका आधारमा मात्र समावेशीकरणलाई हेरिनुहुँदैन। यसले गर्दा नेपालमा 'शोषक र शासक' भनी नयाँ डिस्कोर्समा चिनिएका जातहरूको ठूलो तप्का बहिस्करणमा परेको देखिन्छ। सो कथित 'शोषक र 'शासक' का सबै व्यक्तिहरू नेपालजस्तो आर्थिक रूपमा विपन्न देशमा अरू 'शासित' भनिएका व्यक्तिहरूभन्दा समृद्ध नहुन सक्छन्। यस्तो अन्यायपूर्ण 'लादिएको'
प्रावधानका 'खोट' हरूलाई समयमै नसुधारेमा पक्कै पनि सबै नेपालीलाई सुखी नेपाली नबनाउने मात्र होइन, यसले समाजमा द्वन्द्ध पनि सिर्जना गई्छ।

स्थायी जागिरमा प्रवेश गराउने प्रमुख निकाय लोक सेवा आयोगको पछिल्लो वार्षिक प्रतिवेदन अनुसार आ.व. २०७६/०७७ मा नेपालका ७७ जिल्लामध्ये सबैभन्दा बढ़ी दरखास्त पर्ने पाँच वटा जिल्लाहरूमा सप्तरी, सर्लाही, धनुषा, सिराहा र कैलाली रहेका छन् भने सबैभन्दा न्यून दरखास्त पर्ने जिल्लाहरु क्रमश: मनाङ, मुस्ताङ, रसुवा, डोल्पा र मुगु रहेका छन्। त्यस्तै प्रदेश नं २ बाट सबैभन्दा बढी र कर्णाली प्रदेशबाट सबैभन्दा न्यून संख्यामा दरखास्त परेको देखिन्छ (लोक सेवा आयोग, २०७७, पृ.i-ii)। यसले प्रवृक्तिले के देखाउँछ भने कथित उपल्लो र 'शोषक/सामन्ती' जाति/समुदायको अधिकांशतः बाहुल्य रहेको कर्णाली प्रदेशबाट कम मात्र राज्यका निकायहरूमा पहुँच देखिन्छ भने केही देशीविदेशी अध्येता, एक्टिभिस्टहरुले दाबी गरेकैं मधेशका उपल्लो जातको राज्य संरचनामा कम पहुँच नभएको देखिन्छ। तथापि मधेशमा मुसहर लगायत कथित तल्लो जातलाई आरक्षण, समावेशीकरणले खासै लाभ पुयाएको देखिन्न। त्यसो त विकट हुम्ला, डोल्पाका मान्छेलाई सबैभन्दा नजिकको प्रदेश राजधानी सुर्खेत वा संघीय राजधानी काठमाडौंबाट लाभ लिन राज्यका आधारभूत पूर्वाधार सडक लगायतमा गतिलो पहुँच भएको सप्तरी, मोरङ, कास्की, मकवानपुरभन्दा गाह्रो अवश्य हुने नै भयो ।

सुर्खेतमा हुने नेपाली सेनाको अधिकृत क्याडेटको परीक्षामा सहभागी हुन डोल्पाको उम्मेदवारलाई भन्दा सुर्खेतको उम्मेदवारलाई खर्चको हिसाबले कम लाग्ने नै भयो। यो त एउटा प्रतिनिधि उदाहरण मात्र हो । राज्य, गैरराज्यका हरेक संरचनामा समावेशीकरणका लागि भूगोल, पहुँच, स्रोत, सम्बन्ध, पूर्वाधार आदि पक्षहरुले ठूलै फरक पार्ने गर्दछन् । एउटा उदाहरण प्रस्तुत गर्दा विगतको कर्णाली अन्चलबाट कथित उपल्लो जातको बाहुल्य हुँदाहुँदै त्यस क्षेत्रबाट नेपाली सेना लगायत 
राज्यका अड्गहरूमा न्यन प्रतिनिधित्व रहेको देखिन्छ। त्यसमा तत्कालीन जुम्ला राज्यले अन्य राज्यहरू सल्यान, जाजरकोट भैं तत्कालीन सत्तासँग सजिलै 'आत्मसमर्पण' को नीति नलिनु अनि काठमाडौंले त्यस भेगप्रति लिएको 'बदला' को भावनाले पनि काम गरेको पाईन्छ (शाह, २०पू७, प्. १२)। त्यसैले त विगतको कर्णाली अन्चलका जिल्लाहरु जुम्ला, हुम्ला, मुगु, कालिकोट, डोल्पाबाट नेपाली राज्यका अडुहरुमा असाध्यै कम प्रतिनिधित्व भएको थियो। राजनैतिक पार्टी, निजामती सेवा, नेपाली सेना, नेपाल प्रहरी, सशस्त्र प्रहरीबल, नेपाल सार्वजनिक संस्थानहरु, विश्वविद्यालय, सऊ्चार माध्यम, निजी क्षेत्र, वैदेशिक रोजगारी लगायतमा त्यस क्षेत्रको उपस्थिति न्यून छ। त्यसैले त राज्यबाट 'पीडित' दाबी गर्ने मधेशी, दलित, आदिवासी जनजाति, महिला अगुवाहरु/एक्टिभिस्ट, लेखक, राजनीतिजहरु जो प्राय: काठमाडौं केन्द्रित छन् तिनले कर्णाली जस्तो वा जुम्ला, हुम्ला विशेष गरिबी, अभाव, असमावेशी, भोकमरीको सट्टा प्रयोग गर्ने गरेको पाइन्छ।

नेपालमा २६.६ प्रतिशत जनसंख्या बहुआयामिक रूपमा गरिब रहेका छन् जसको प्रमुख कारण न्यून पोषण र त्यस्ता घरधुरीहरु जसको परिवारको कुनै पनि सदस्यले $y$ वर्षको विद्यालय शिक्षा पूरा गरेको छैनन् भनी जनाएको छ (National Planning Commission: 2018, p. viii) । त्यस्तै, सहरी जनसंख्या ७ प्रतिशत र ग्रामीण जनसंख्या ३३ प्रतिशत गरिब रहेको तथ्याकं छ, जसले सहर र गाउँ बिचको विभाजन स्पष्ट पारेको छ। कर्णाली प्रदेश ६ र प्रदेश नं २ मा सबैभन्दा उच्च दर (प० प्रतिशत) मा बहुआयामिक गरिबी रहेको छ, जहाँ प्रत्येक दोस्रो व्यक्ति बहुआयामिक रूपमा गरिब पाइएको थियो ।

\section{अन्तर्राष्ट्रिय एजेन्सीहरुमा समावेशीकरण}

सन् २००६ मा नेपालमा कार्यरत ३० वटा अन्तरराष्ट्रिय एजेन्सी (संयुक्त राष्ट्र संघीय निकायहरु, द्विपक्षीय र बहुपक्षीय दाताहरु नेपालमा रहेका विदेशी राजदूतावास
सहितमा ) हरुमा गरिएको समावेशीकरणको अध्ययनमा नेवार समुदाय नेपालमा रहेका अन्तर्राष्ट्रिय एजेन्सीहरुमा सबैभन्दा बढी (२६.३ प्रतिशत ) प्रतिनिधित्व भएको पाइएको थियो (Social Inclusion Action Group, 2008, p. vi)। त्यस्तै, महिलाको प्रतिनिधित्व २९.३ प्रतिशत र सिनियर व्यवस्थापनमा २ू प्रतिशत रहेको देखाएको छ (Social Inclusion Action Group, 2008, p. vi)। सो अध्ययनमा पाइएनुसार अन्तर्राष्ट्रिय एजेन्सीहरुमा समानुपातिक प्रतिनिधित्व पुय्याउन अन्य मधेशी जात समूहहरुको १२ प्रतिशत, तराई जनजाति समूहो $७$ प्रतिशत, पहाडे दलित समूह $\checkmark$ प्रतिशत साथै मधेशी दलित र मुसलमानको ३ प्रतिशतले बढाउनु जरुरी देखिएको थियो (Social Inclusion Action Group, 2008, p. vi)। त्यस्तै, लैड्गिक रुपमा महिलाको प्रतिनिधित्व २९.३ प्रतिशत मात्र देखिएको थियो (Social Inclusion Action Group, 2008, p. vi)

नेपाली सेनामा समावेशीकरण

विविधता, समावेशीकरण र सम्मान नेपाली सेनाको प्रमुख पक्षहरु हुन। नेपाली सेनाले विश्वकै सर्वोत्कृष्ट सेना हुन सेनाको भर्ना प्रकिया, अवसरमा सबै वर्ग र समुदायका व्यक्तिहरुलाई उक्तिकै अवसर दिनु जरुरी देखिन्छ, (Ministry of Defence UK, 2020)। सेनाभित्र समावेशीकरणको अनुभव, मूल्य र दक्षताले सेनालाई युद्धूा उपलब्धि हासिल गर्न सघाउँ (Army People Strategy, 2020)। साथै सजातीय (Homogenous) भन्दा बहुजातीय (Heterogeneous) मुलुकहरुमा सामाजिक सद्भाव र राष्ट्रिय एकताको चुनौती र महत्व हुने मत विश्लेषकहरुको छ (सिलवाल, २०७७,पृ.७४)। संयुक्त राज्य अमेरिकामा $9 ९$ औं शताब्दी देखि नै विगतमा बहिष्कृत समूहलाई सेनामा एकीकृत गर्ने प्रयास भएको पाईन्छ (Kamarck, 2017)। नेपाल चार वर्ण छत्तीस जातको फललबारी हो भनी पृथ्वीनारायण शाहले विविधता र समावेशीकरणलाई अर्थ्याउन खोजेका थिए । त्यस्तै हालको नेपालको "राष्ट्रिय गानले पनि 
सयौं थुड़गा फ़लका हामी एउटै माला नेपाली" भनी अभै पनि नेपाललाई विविधता बिचको एकताका रुपमा अर्थ्याएको पाइन्छ, (सिलवाल, २०७७, प. ७४)। नेपाली सेनामा ५७,९७२ दरबन्दीमा दलित ७,१६३ अर्थात् ५ प्रतिशत रहेको देखाउँछ (राष्ट्रिय मानव अधिकार आयोग :२६, २०७७।। विविधता सहितको सेनाले सम्पूर्ण समाजमा न्याय प्रवर्द्धन र सबै समाजका सदस्यहरुलाई मानवीयता प्रवर्द्धन गराउन सघाउँछ। समावेशी भएर नै नेपाली सेना सबैभन्दा ज्यादा 'विश्वासिलो' संस्था हुन पुगेको छ। सन् २०१७ मा भएको एउटा सर्वेक्षणमा नेपाली सेनालाई इ७.९ प्रतिशत सर्भेक्षण गरिएका मानिसहरुले विश्वास गरेको देखिएको थियो (The Asia Foundation, 2017, p. 70) .

नेपाली सेनाको कोर रेजिमेण्टहरू नेपाली राज्यको उदय हुनुभन्दा अघिदेखि थियो जसमा मगर, गुरुङ लगायत जनजाति समहहरु रहेका थिए। नेपाली सेनासँग अन्य धनी राज्यको तुलनामा अत्याधुनिक हतियार, सैनिक उपकरण र पर्याप्त लजिस्टिक्सको अभाव भए पनि यसको ऐतिहासिकता र सझ्गठनात्मक एकता नेपाली राज्यका अन्य अड्गहरूमा पाइदैन। यो संस्था प्रत्यक्ष रूपमा सुरुदेखि नै नेपाली राष्ट्र-राज्य निर्माणमा संलग्न रही आएको छ (Shah, 2004, p. 214)। त्यस्तै, मानवीय मिसनमा गएको समावेशी सेनाले दून्द्रग्रस्त क्षेत्रमा सेना र स्थानीय समुदायबिच प्रभावकारी रुपमा समन्वय कायम गर्न सक्दछ। सेना परिचालन गर्दा जाति, धर्म ,लिड्ग, धर्मजस्ता विविधता सहितको पक्षलाई ख्याल गरी उनीहरुले विविधतालाई सजिलै बुक्ने, सम्मान गर्ने र त्यसले अन्ततः राम्रो परिणाम ल्याउने गर्दछ (Richardson et. al, 2014, p. 38)। विविधता र समावेशीकरण कार्यक्रम सेनाको कार्यसम्पादन बढाउन बढ़ी जरुरी हुन्छ, परम्परागत समान अवसरभन्दा यो रणनैतिक रुपमा सक्षम सेना बनाउनु उपयुक्त हुन्छ।(McDonald et. al., 2016, p. 38). परम्परागत रुपमा क्षत्री समुदायको नै नेपाली सेनामा ज्यादा प्रतिनिधित्व रहिआएको छ भने राजनैतिक संरचना, निजामती सेवा, सञ्चार माध्यम र नागरिक समाज लगायतमा ब्राम्हण समुदायको ज्यादा प्रतिनिधित्व रहिआएको छ। त्यस्तै, दलित जनसंख्या १३.६ प्रतिशतको हाराहारी भए पनि नेपाली सेनामा तिनको प्रतिनिधित्व ६.०४ प्रतिशत मात्र छ जुन तल्लो पदहरुमा मात्र ज्यादा रहेको पाइन्छ। त्यस्तै, तराईमा भएका जातिहरुको जनसंख्या लगभग ३० प्रतिशत भए पनि उनीहरुको नेपाली सेनामा $y . \gamma 5$ प्रतिशत मात्र प्रतिनिधित्व रहेको छ (Shah, 2009)। २०६९ सालसम्म भएका ४१ प्रधान सेनापतिमध्ये राणा २७, थापा र पॉडे $\gamma / \gamma$, शाह र बस्यात $\vee / २$, कटवाल र गुरुड़ १/१ थिए (शर्मा २०६७ का २०७०, पृ. १६७ मा उद्धृत्)।

भर्नाले नेपाली सेनालाई समावेशी राष्ट्रिय 'चरित्र' प्राप्त गर्न सघाउँछ जसले विविधता सहितको देशकै प्रतिनिधित्व गर्ने सैन्य शक्ति पाउन सजिलो पार्दछ। यसका लागि नेपाली सेनाले 'आउटरिच' लगायतका रणनीतिबाट कम प्रतिनिधित्व भएका समुदाय, जात, वर्ग, लिड्ग, क्षेत्रबाट योग्य र सक्षम उम्मेदवारहरु सेनामा भर्ना गर्न सक्छ (Lim et. al., 2013, p. xiii)। यसका लागि नेपाली सेनामा कम प्रतिनिधित्व भएका उम्मेदवारहरु भएका क्षेत्र, वर्ग, लिड्ग, जात भएका क्षेत्रहरुलाई पायक तथा सहज पर्ने ठाउमा भर्ना प्रक्रिया लाने, अनि भर्ना प्रकियालाई बढ़ी विश्वसनीय एवम् सहज बनाउने अनि त्यो क्षेत्र, वर्ग, समुदाय, लिड्ग, जातबाट बढ़ी योग्य उम्मेदवारहरुलाई नेपाली सेनामा आकर्षण गर्न विभिन्न रणनीतिहरु अँगाल्नु जरुरी देखिन्छ। यसले गर्दा उनीहरुको 'फरकपना' ले उनीहरुलाई नेपाली सेनामा भर्ना हुन सकिदैन भन्ने गरी 'लादिएको' मान्यताबाट उनीहरुलाई बाहिर निकाल्न सकियोस् (Lim et. al., 2013, p. xiii)। 
नेपाली सेनामा विभिन्न जात/समूहो प्रतिनिधित्वको अवस्था

\begin{tabular}{|c|c|c|}
\hline जात / समूह & $\begin{array}{l}\text { जनसंख्या } \\
\text { प्रतिशतमा }\end{array}$ & $\begin{array}{c}\text { नेपाली सेनामा } \\
\text { प्रतिनिधित्व } \\
\text { प्रतिशतमा }\end{array}$ \\
\hline क्षत्री & $9 \xi . \xi$ & ४२. 999 \\
\hline ब्राम्हण (खस) & १२.२ & ๘. ७२० \\
\hline मगर & ৩. ३ & Б.३९૪ \\
\hline नेवार & 4.9 & y. ७०२ \\
\hline तामाड & $y$ & $\gamma . \rho \xi \gamma$ \\
\hline गुरुड & 9.9 & २.९७१ \\
\hline राई & २.३ & २. ४५७२ \\
\hline लिम्बू & 9.8 & 0.993 \\
\hline शेर्पा & 9.5 & $0.9 ३ ३$ \\
\hline
\end{tabular}

स्रोत : केन्द्रीय तथ्याक विभाग, २०६५; (Nepal Army. 2019)

\section{नेपाली सेनामा महिला}

अभिलेखित रूपमासेनामा महिलाहरूको उपस्थिति थुप्रै संस्कृति र देशहरूमा लगभग चारसय वर्ष पुरानो मानिन्छ (Munshi 2017,p. 1) । महिलाहरुलाई सफल रुपमा सुरक्षा संरचनामा समायोजन गर्दा परिमाणात्मक मात्र नभएर गुणात्मक समायोजन आवश्यक छ जसले पितृसत्तात्मक सामाजिक मूल्य मान्यतालाई चुनौती दिने मात्र होइना, सकारात्मक परिवर्तन पनि ल्याउँदछ (Kunz 2014, as cited in Racovita, 2018, p. 4)। त्यस्तै, सुरक्षा क्षेत्रमा काम गर्ने नेपाली महिलाहरुले हिंसात्मक पुरुषत्वलाई चुनौती दिन प्रमुख भूमिका खेल्नुका साथै सुरक्षा क्षेत्र पुरुष अन्तर्गत मात्र रहनुपई्छ भन्ने मान्यतालाई परिवर्तन गर्दछ (Kunz, 2018, p. 4-5)। महिलाहरुले खाली अहिले प्रायजसो प्रयोगमा आइरहेको 'सफ्ट' सुरक्षा भूमिकाबाट बाहिर ननिस्के सम्म पुरानै पितृसत्तात्मक सोच सुरक्षा क्षेत्रमा पनि हावी भइरहन्छ (Gosewinkel and Kunz 2014, as cited in Racovita, 2018, p. 5)। महिलाहरुले सेनामा सेवा गर्न खासगरी 'कम्याट' भूमिकामा उनीहरुको
शारीरिक अनि साहसको कमीले गर्ने सक्दैनन् भन्ने धारणा धेरै पहिलेदेखि नै रहंदै आएको थियो (Cohn, 2000; Goldstein, 2001; MacKenzie, 2015 as cited in Wilen and Heinecken, 2017)। अर्को विचार के पनि छ भने महिलाहरुले महिला भएकै कारण सेनामा केही 'युनिक' योगदान गर्न सक्छन् जसले सेनालाई ज्यादा विविधतायुक्त गर्न सक्छ (Cohn, 2000; Goldstein, 2001; MacKenzie, 2015 as cited in Wilen and Heinecken, 2017)। हाम्रो छिमेकी भारतमा सन् १९२७ देखि मिलिटरी नर्सिड्ग सेवाबाट महिलाहरुलाई सेनामा लिन थालिएको थियो (Munshi, 2018, p. 1)। त्यस्तै, नर्वेमा महिलाहरुलाई सन् १९६रू मा सेनामा औपचारिक पहुँच दिएको थियो (The Norwegian Defence University College, 2010, p. 12)। विश्वभर कम्तीमा १६ वटा देशहरुले महिलाहरुलाई सेनामा 'कम्ब्याट' भूमिकामा सेवा गर्न दिएका प्रमाणहरु छन् (WION, 2020)। सन् २०१६ को प्रतिवेदनअनुसार उत्तर एटलान्टिक सन्धि सझ्गठ (The North Atlantic Treaty Organization NATO) का २२ वटा प्रतिवेदन प्राप्त देशहरुमध्ये 'एक्टिभ ड्युटी' मा रहेका सैनिक महिलाहरु ११.३ प्रतिशत रहेको थियो (NATO, 2018, p. 15) . NATO अन्तरगतका प्रतिवेदन प्राप्त देशहरुमा एक्टिभ ड्युटी' मा रहेका सैनिक महिलाहरुलाई लैड़िक दृष्टिले हेर्दा हंगेरीमा सबभैन्दा ज्यादा $9 ९ . ९$ प्रतिशत र सबैभन्दा कम टर्कीमा १.२ प्रतिशत सेवारत देखिन्छन् (NATO, p. 17)।

नेपालको सन्दर्भमा निजामती सेवामा जम्मा द३,००० जना सेवारतमध्ये २० प्रतिशत महिलाहरु रहेका छन् । त्यस्तै नेपाल प्रहरी, सशस्त्र प्रहरीबल नेपाल र नेपाली सेनामा ऋमश: $y . \vartheta, ~ ४ . ९$ र ३.२ प्रतिशत महिला जनशक्तिको प्रतिनिधित्व भएको पाइन्छ (International Labour Organization, 2018, p. 4)। नेपालको पहिलो अभिलिखित महिला लडाकूहरुको तथ्याकं नालापानी युद्ध (सन् १६१४-१६) मा तत्कालीन नेपाली गोर्खा सैनिकले तत्कालीन ब्रिटिश इस्ट इण्डिया 
कम्पनीको फौजसँग लडेको पाइन्छ (Adhikari 2015, as cited in Racovita, 2018, p. 6)। नेपाली सेनाले महिलाका लागि भर्ना प्रकिया प्राविधिक सेवामा सन् १९६१ देखि खुला गरेको थियो भने साधारण सेवामा सन् २००४ देखि मात्र भर्ना प्रकिया सुरु गरेको पाईन्छ (Nepal Army, 2019)। यसको साथै नेपाली सेनाले नेपाली सेनाका अधिकृत महिलाको वृत्ति र कल्याणसॅग सम्बन्धित मुद्दाहरु सम्बोधन गर्न महिला विभागको स्थापना गरेको छ। महिला अधिकृतमध्ये सामान्य सेवामा १६३ र प्राविधिक सेवामा २१४ रहेका छन्। सन् २०१९ को तथ्याकंअनुसार नेपाली सेनामा महिलाहरुको संख्या जम्मा $4,0 ६ २$ रहेको थियो (Nepal Army, 2019)। नेपाली सेनामा सन् २०१४ को तथ्याक अनुसार महिला सैनिक अधिकृतहरुको संख्या ३०६(१७.२) प्रतिशत रहेको छ जुन नेपाल प्रहरीमा ०.y प्रतिशत मात्र छ (Racovita, 2018)। त्यसै गरी नेपाली सेनाले सन् २०१४ बाट सन् २०१७ को सुरुमा नेपाली सेनामा महिलाको संख्या १,७७६ बाट ४,०९ ४ पुच्याएको छ, (Kathmandu Post, 2014; Chauhan, 2017 as cited in Racovita. 2018, p. 9,)। सन् २०१४ मा राई, लिम्बू, गुरुङ, मगर, तामाङ, नेवार, ब्राम्हण, क्षत्री, दलित र चौधरी समुदायहरुबट जम्मा १४६ जना महिलाहरुले नेपाली सेनाको आधार भूत सैनिक तालिम सकेका थिए जसबाट पनि नेपाली सेनाले समावेशीकरणतिर पाइला बढाईरहेको स्पष्ट हुन्छ, (Kathmandu Post, 2014)। सन् २००३ बाट नेपाली सेनाले 'कम्ब्याट' पदहरुमा महिलाहरुलाई भर्ना लिन थाल्यो (Lohani-Chase, 2008)।

नेपाली सेनाले महिलामैत्री वातावरणहरु सिर्जना गरेको छ। महिलातर्फ नेपाली सेनाबाट महिला सैनिक अधिकृतका रुपमा पहिलो पटक संयुक्त राष्ट्र संघीय शान्ति मिसनमा सहभागी प्राविधिक महा सेनानी डा. सरिता केसीले मिसनमा जाँदा महिला र बच्चाहरुको राम्रो स्वास्थ्य सेवा प्रदान गरेकी थिइन। यसका साथै, मिसनमा महिला बिरामीहरुले चिकित्सकसँग महिला भएको नाताले मनको कुरा खोल्न एकदम सजिलो
भएको अनुभव गरेकी छिन् (Kathmandu Post, 2014)।

नोभेम्बर २०२० को तथ्याक अनुसार हाल नेपाली सेनाबाट विश्वभर जम्मा १२ वटा संयुक्त राष्ट्र संघीय शान्ति मिसनहरुमा जम्मा ४,१३२ सेनाहरु खटिएकोमा महिलाहरुको संख्या १६५ रहेको छ।

अर्की नेपाली सेनामा विद्यावारिधि गर्ने पहिलो सैनिक अधिकृत प्राविधिक सहायक रथी डां नर्वदा थापा महिलाहरुले हीनभावना त्यागी पुरुषहरुसँग प्रतिस्पर्धामा उत्रन आग्रह गर्छिन्। त्यस्तै महिला सैनिक पाइलटको रुपमा पहिलो ब्याचकी महिला पाइलटहरु अनिता आले मगर र निरु ढुंगानाले नेपाली सेनाले महिलाहरुका लागि राम्रो अवसर प्रदान गरेको अनुभव बाँडेकी छन् जसले गर्दा नेपाली सेनाप्रति सम्मान बढेको बताएकी छन्। त्यसरी नै नेपाली सेनाले महिला भएक कारण फरक हुँ भन्ने अनुभव हुन नदिएको निरु ढुंगानाको अनुभव रहेको छ। सन् २०१९ फेब्रुअरीसम्म नेपाली सेनाबाट जम्मा १०१९ जना महिला सैनिकहरु शान्ति सेनाका रुपमा खटिएको तथ्याक नेपाली सेनाले सार्वजनिक गरेको छ। नेपाली सेनाबाट महिला सैनिक पर्यवेक्षकका रुपमा पहिलो पटक संयुक्त राष्ट्र संघीय शान्ति मिसनमा सहभागी सेनानी कृति राजभण्डारीले आफू सो मिसनमा जाँदा महिलाहरुलाई स्वतन्त्र रुपमा र विश्वास गरेर पठाइएकोमा नेपाली सेनाको तारिफ गरेकी छन् पाइन्छ।

सेनानी गीता गुरुड्गलाई पहिलो पटक युनिट कमाण्डरका रुपमा संयुक्त राष्ट्र संघीय शान्ति मिशनमा महिला अधिकृतबाट खटाइएका थियो ।

सेनानी सृष्टि खड्का (पहिलो महिला, गोरखकाली गुल्म, गुल्मपति) का अनुसार महिलाहरुका लागि छुट्टै गुल्मले गर्दा महिलाहरुको वृत्ति विकास र करिअर पाथका लागि कोसेढुड्गा हुने कुरो बताएकी छिन्। नेपाली सेनाको चिकित्सा सेवामा कमशः महिलाहरुको संख्या उल्लेख्य रुपमा बृद्धि भएको पाइन्छ। नेपाली सेनाले विना भेदभाव महिलाहरुलाई विभिन्न चाहे त्यो शान्ति 
सेनामा होस् (Chand, 2020) वा कोभिड 99 बाट मृत्यु भएको शव व्यवस्थापनमा ह्रास (Maharjan, 2020; Sharma, 2020) नेपाली सेनाका महिलाहरुले उत्कृष्टताका साथ जिम्मेवारी निर्वाह गरेको पाईन्छ। पन्चानब्बे हजारको हाराहारीमा रहेको नेपाली सेनाका महिलाहरुले शव व्यवस्थापन जस्तो कार्य गर्नुले उनीहरुको सशक्तीकरण हुनुका साथै रुढीवादी चलन वा रुपमा रहेको महिलाहरुले मरेको लाश छुनु हुँदैन भन्ने मान्यतालाई चुनौती दिएको छ।

पछिल्लो पटक बेलायतको रक्षा मन्त्रालयले सन् २०१६ बाट गोर्खा ब्रिगेडमा पहिलो पटक नेपाली महिलाहरुलाई पनि भर्ना लिने भने तापनि बेलायतको संसदीय समितिले मार्च २०१९ मा भर्ना नलिने भनेको छ (Deupala, 2019) ।

बेलायतको गुर्खा ब्रिगेड होस् वा भारतको गोर्खा रेजिमेण्टले निश्चित वर्ग, लिड़्ग, जातका मानिसहरुलाई मात्र उनीहरुको सेनामा भर्ती गर्ने गरेको पाईन्छ। साथै युद्धमा मरेपछि, नेपालीहरुको लाशको अन्तिम संस्कारका लागि नेपालमा सम्बन्धित परिवारले ल्याउने, मरेको नेपाली सैनिकको परिवारले पेन्सन पाउने भलै त्यहॉका सेवानिवृत्त सैनिक, पत्रकार, प्राजहरुले नेपाली सेनाको समावेशी चरित्रलाई बेलाबेला समावेशी भएन भनेर आलोचना गरेका पाइन्छ (Ghimire, 2016)। भारतीय पूर्व गोर्खाको फेडरेशनले भारतीय सैनिक र नेपाली गोर्खाहरू बिच 'विभेद' को मुद्दा लगातार उठाउँदै आएको छ, तर महिला सैनिकबारे जसको यथोचित सम्बोधन भएको पाँइदैन ।

भारतीय गोर्खा रेजिमेण्टमा मधेशीहरुको पू० प्रतिशतको हाराहारीमा भर्नाका लागि कोटा निर्धारण हुनुपर्ने एक प्रभावशाली मधेशी नेताले सन् २०१६ मा भएको तत्कालीन प्रधानमत्त्री पुष्पकमल दाहालको भारत भ्रमणको दौरान भनेको थिए। त्यस्तै मुद्दा सन् 9990 मा तत्कालीन प्रधानमन्त्री कृष्णप्रसाद भट्टराईको भारत भ्रमणको दौरान उनका समकक्षी भारतीय प्रधानमन्त्री भि. पी. सिंहसँगको संयुक्त पत्रकार सम्मेलनमा भारतीय पत्रकारले सोधेका थिए। त्यसको जवाफमा नेपालका
प्रधानमन्त्री कष्णप्रसाद भट्टराईले सो पत्रकारलाई किन भारतले मधेशीहरुलाई भारतीय गोर्खा रेजिमेण्टमा भर्ना लिदैन भनी भारतीय प्रधानमन्त्रीलाई देखाउँदै सोधन भनेका थिए। त्यस्तै गुर्खा भेटेरनहरूले गोर्खाहरुप्रति पेन्सन लगायतमा भएको 'विभेद' विरूद्ध वर्षोदेखि संघर्ष गर्दे आएको पाईन्छ, (Budhathoki, 2019)।

ब्रिटिसहरुले जात प्रणाली वा आधारमा गोर्खा सेनामा उनीहरूको नीति र व्यवहारमा कायम गर्दे आएको छ, जसले गोर्खा सेनाको भर्तीमा हालसम्म निश्चित जात जातिको व्यक्तिहरूलाई मात्र भर्ना लिने गरेको छ, भलै ब्रिटिस अध्येता वा सेवा-निवृक्त सेना लगायत तथा उनीहरूबाट प्रत्यक्ष-अप्रत्यक्ष रूपमा सहयोग प्राप्त नेपाली अध्येता, एक्टिभिस्ट, पत्रकार, राजनीतिज्ञहरूले नेपाली सेना असमावेशी चरित्रको भयो भनी आरोप लगाउने गरेको छ, (Cowan, 2012, as cited in United Nations Resident and Humanitarian Coordinator's Office, 2013, p. 2; Pariyar, 2020, p. 613) । ब्रिटिश सेनामा कसरी चार वटा जातहरू : गुरुड, मगर, राई, लिम्बू मात्र भर्नाका लागि लिने गरेको छ, जब कि नेपालका १२४ जातजातिबाट लिनु पर्नेमा प्रश्न उठाइएको छ (Yadav 2017, as cited in Pariyar, 2020: 612) । अहिले पनि बेलायतको रक्षा मन्त्रालयले ब्रिटिस गोर्खा सेनामा सबै जात र क्षेत्रलाई खुला गर्ने भने तापनि त्यही पुरानै तोकिएका 'मार्सल' जातहरूलाई मात्र अधिकांशतः भर्ना लिने गरेको छ, (Pariyar, 2018)।

\section{नेपाली सेनामा जनजाति}

सबै जनजाति समूहहरु किनारामा परेको भनेर पनि भन्न नमिल्ने विश्लेषण केही अध्येताको छ, (Joanna PfaffCzarnecka :1997)। विभिन्न जनजाति समूहहरु निजी व्यवसायीको रुपमा विशेष गरी पज्चायत कालमा स्थापित भएको पाइन्छ (Zivetz, 1992)। त्यस्तै गोर्खा सैनिकका रुपमा (मगर, गुरुड, राई, लिम्बू); दुर्गम बोर्डर क्षेत्रमा कर संकलन गर्नेको सन्तान 'सुब्बा' का रुपमा (थकाली, शेर्पा, मनाडी) का रुपमा राम्रै आर्थिक, सामाजिक अवस्था हासिल गरेको देखिन्छ। 
जनजाति समहहरु नेपाल सरकारको सरकारी, गैरसरकारी सेवा, संस्थान, विश्वविद्यालय, नेपाली सेनामा सेवारत रहेको पाइन्छ। त्यसरी नै विदेशी दाता अनि विदेशी व्यवसायीहरुसँग दिगो सम्बन्ध राखेका केही जनजाति समूहहरु विभिन्न आर्थिक क्षेत्रमा राम्रैसँग स्थापित भएको छन्। तिब्बती शरणार्थीहरु गलैंचा व्यवसायमा र 'भोटे' खास गरी शेर्पा समुदाय पर्यटन व्यवसायहरुमा स्थापित भएका छन्। साथै थकाली, गुरुड र मनाडी समुदायका व्यक्तिहरु पहाडे र नेवार समुदायसँगै सबै प्रकारका आयात निर्यात व्यापारमा स्थापित भएका छन् (Pfaff-Czarnecka,1997)। आदिवासी जनजाति समूहभित्र पनि केही 'एलिट' समूह/व्यक्तिहरुको हातमा आर्थिक पहुँच र राजनैतिक शक्ति केन्द्रित हुन गएको छ (Shrestha, 2012)। सन् २००१ को तथ्याङ्कनुसार साक्षरता सूचकमा थकाली, नेवार, व्यासी, ह्योल्मो समूह/जातिहरुको पहाडे ब्राम्हण जत्तिकै (७Y.६ प्रतिशत) देखिन्छ। साथै थकाली, नेवार, व्यासी, ह्योल्मो, गुरुड, लिम्बु, याक्खा, दराई, छन्त्याल, जिरेल, दूरा, राई, मगर समूह/ जाति हरुको सन् २००१ को तथ्याकं अनुसार राष्ट्रिय औंशत (५३.७ प्रतिशत) भन्दा माथि उक्लेको देखिन्छ (NHDR 2004 :63, as cited in Mahat 2011)।

सन् २००१ को तथ्याकंअनुसार 'शासक' का रुपमा चित्रित क्षेत्री जनसंख्याको बाहुल्य रहेको जुम्ला जिल्लाको साक्षरता दर पुरुषको ४७ प्रतिशत र महिलाको १६.५ प्रतिशत अनि समग्रमा ३२.५ प्रतिशत मात्र देखिन्छ ।

यस्तो क्षेत्रीय असमानताले नेपाली सेना लगायतमा तत्कालीन कर्णाली अन्चल लगायतबाट कम प्रतिनिधित्व वा तल्लो तहमा मात्र प्रतिनिधित्व हुने देखिन्छ।

जुम्लाका मानवशास्त्री सौभाग्य शाहले २०४७ सालमा कर्णालीको राज्य संरचनामा समावेशीकरणको दयनीय अवस्थाबारे यसरी चित्रण गरेको छ् :

जातकै मात्र सवाल हुँदो हो त यहाँका ठूला जात भनाउँदाले त्यस्तो प्रगति गरेको भेटिनुपर्थ्यो। अरू त कुरै छोडों, हालसम्म कर्णालीका पाँच जिल्लाबाट
कसैले पनि निजामती, प्रहरी वा शाही सेनामा अधिकृत स्तरबाट प्रवेश पाएका छैनन् । नागरिकता, राहदानी र प्रमाणपत्रहरू तयार गर्दा पनि कर्णालीबासीहरूले ठूलै भमेला खेप्नुपछ। किनकि कागजहरू प्रमाणित गरिदिने 'राजपत्राड्कित अधिकृत' हरूले उनीहरूलाई चिनेका हुँदैनन्। आफू जुम्ली (कर्णालीबासी) भएको कुरालाई पनि अनेक जी, हजुरी चढाएर बाहिरका अधिकारीहरूबाट आधिकारिक बनाउनुपर्ने स्थिति छ (शाह: २०पै७, पृ. १२)।

यसै सन्दर्भमा मे.डी. भट्टराई भन्दछन् मगर, नेवार, गुरुङ, राई, दमाई/धोली, घर्ती/भुजेल, ठकुरी, सन्यासी, कुमाल, हजाम/ठकुरी, दराई / जिरेल जाति / समूहहरुको नेपाली सेनामा जनसंख्याको अनुपातमा केही बढी प्रतिनिधित्व देखिन्छ। त्यस्तै, नेपाली सेनामा ब्राम्हण, तामाड, कामी, लिम्बू, कामी, सार्की, र थारु समुदायको जनसंख्याको अनुपातमा थोरै मात्र कम प्रतिनिधित्व भेटिन्छ (Bhattarai, 2009)।

सन् २००६ मै नेपाली सेनाको तथ्याकंले निर्णय गर्ने तहका पदहरु (मेजर जनरल र सोभन्दा माथिका दुई प्राविधिक पदहरु सहित) मा क्षेत्री समूहबाट द; लिम्बू, ब्राम्हण, गुरुङ र ठकुरी समूहबाट २, २; राणा र नेवार समूहबाट १,१ जना रहेको तथ्याक सार्वजनिक गरिएको थियो। त्यस्तै जयन्त राना जो मगर समुदायबाट थिए पृथ्वीनारायण शाहका पालामा सबैभन्दा सफल सेनाका कमाण्डर थिए ।

तर सन् २०१९ मा आउँदा त्यस्तै तामाङको समूहको जनसंख्याको अनुपातमा केही कम मात्र देखिन्छ भने लिम्बूको पनि जनसंख्याको अनुपातमा कम देखिन्छ भने शेर्पाको अभै थोरै देखिन्छ (Nepal Army. 2019)।

\section{नेपाली सेनामा मधेशी}

विगतको 'तरल' राजनीतिको फाइदा उठाउँदै विभिन्न नेताहरुले विभिन्न आन्दोलनकारी नेता,तथा शक्तिहरुसँग विभिन्न संकौताहरु गरेका थिए जसअनुसार केही मधेश केन्द्रित दलहरुले नेपाली सेनामा मधेशीहरुको सामूहिक र ठूलो संख्यामा भर्नाको माग सन् २००९ मा उठाएका थिए । 
मधेशीहरुको 'राजनैतिक सशक्तीकरण' र 'वेल बिईड्ग' मा छि,मेकी भारतको सुरक्षा चासो जोडिएको भनेर भारतका प्रभावशाली कूटनीतिज्ञाट आवाज उठेको थियो (Saran, 2020)।

त्यस्तै माग छिमेकी भारतमा पनि चुनावको बेलामा उठाइएको थियो। भारतमा सन् २०१९ को चुनाव ताका जातका आधारमा भारतीय सेनामा छुट्टै रेजिमेण्टको माग भएको थियो (Hasnain, 2019)। लेफिटनेण्ट जनरल हसनैनले भारतको सन्दर्भमा उल्लेख गरेकें यस्ता मागहरु सेनाको दक्षता बढाउने भन्दा चुनावमा भोटको राजनीतिका लागि मात्र वा सार्वजनिक खपतका लागि मात्र उपयुक्त हुन्छ। यसले सेनाको दक्षता बढाउँदैन ।

त्यस्तै नेपाली सेनाको हकमा पनि नेपाली सेनाले तथ्यका आधारमा विना विभेद नेपालभित्रका प्रत्येक जात, वर्ग, क्षेत्र, लिड्ग, समुदायलाई नेपाली सेनाभित्र उक्तिकै अवसर दिदै आएको छ।

विना अनुसन्धान, तथ्यहीन रुपमा कसैले पनि नेपाली सेनालाई आरोप लगाउनु उचित हुँदैन (United Nations Resident and Humanitarian Coordinator's Office, 2013)। सेनालाई चार पाँच हजारमा मात्र सीमित गर्नुपर्ने तर्क पनि बेलाबेलामा सुनिदैं आएको छ।

छिमेकी भारतमा महिला सैनिक अधिकृतहरुले 'पर्मानेण्ट कमिसन' को माग गरिरहॉदा नेपाली सेनाले महिलाहरुलाई पूर्ण करिअर पाथको अवसरका साथै विना भेदभाव सबै वर्ग, लिड्ग, जात, क्षेत्र, समुदायलाई समेट्न भरमगदुर प्रयास गरेको छ (Economic Times, 2020; WION, 2020)।

नेपाली सेना नेपालको सबैभन्दा पुरानो र भरपर्दो संस्थाका रुपमा कायम रहनुमा यसको समावेशिताको उदार नीतिले गर्दा हो जसले गर्दा नेपालका संड्कटको घडीमा सार्वभौमसक्तालाई बचाउनुका साथै मजबुत बनाउँदै आएको छ।
मधेशीको जनसंख्या सन् २०१९१२ मा ३३. ४ प्रतिशत रहे तापनि नेपाली सेनामा प्रतिनिधित्व ६ प्रतिशत मात्र रहेको छ। त्यसरी नै मधेशी जनजातिको जनसंख्या ६. ५३ रहेतापनि नेपाली सेनामा प्रतिनिधित्व $४ . ५ ?$ प्रतिशत मात्र रहेको र मधेशी दलितको जनसंख्या ४.७ प्रतिशत रहे तापनि उनीहरुको नेपाली सेनामा प्रतिनिधित्व $० . १ ३$ प्रतिशत मात्र रहेको थियो। त्यस्तै, मुस्लिमको जनसंख्या ४. ३९ प्रतिशत रहे तापनि नेपाली सेनामा प्रतिनिधित्व $० .09$ प्रतिशत अर्थात् सबैभन्दा कम रहेको तथ्याकंले देखाउँ।

तराई-मधेशमा त्यहाँको जनसंख्याको प्रतिनिधित्व नेपाली सेनामा बढाउन आरक्षण प्रकियालाई आर्थिक अवस्थाका आधारमा गरेमा वास्तविक गरिब मधेशीहरुले नेपाली सेनामा प्रतिनिधित्व पाउने देखिन्छ।

२०६२/०६३ को राजनैतिक परिवर्तनपशचात् समावेशिताको मुद्दा पेचिलो रुपमा उठेपछि, राज्यका अन्य अड्नहरु कैं नेपाली सेनाले पनि मधेशी समुदायका व्यक्तिहरुको नेपाली सेनामा प्रवेशको लागि कदम चालेको थियो तर त्यतिबेला आशा गरेअनुरुप मधेशी समुदायका व्यक्तिहरु नेपाली सेनामा भर्ना प्रकियामा नै सामेल भएनन् (Bhattarai, 2009)। सन् २००७ र २००६ मा भएको नेपाली सेनाको भर्नामा आशातीत रुपमा मधेशी समुदायबाट सेनामा दरखास्त परेन । सन् २००७ मा भएको नेपाली सेनाको सहायक सेनानी पदमा भएको दरखास्त आह्वानमा जम्मा परेका ४,९९३ दरखास्तहरुमध्ये मधेशी समुदायबाट जम्मा ७६ मात्र दरखास्त परेको थियो। त्यस्तै, सन् २००६ मा भएको सिपाही पदको दरखास्त आह्वानमा जम्मा परेका १४,द२४ दरखास्तमध्ये १,६६३ जम्मा दश प्रतिशतको हाराहारी मधेशी समुदायबाट दरखास्त परेको थियो। जसमा २ जना सहायक सेनानी र द३ जना उम्मेदवारहरु मधेशी समुदायबाट नेपाली सेनामा प्रवेश गर्न सफल भए । (United Nations Resident and Humanitarian Coordinator's Office, 2013) ।

वर्णाश्रम सिद्धान्तको प्रभाव, सामाजिक-आर्थिक मूल्य मान्यता, $q \sqsubset$ औं शताब्दीको तत्कालीन गोर्खाली 
सेनाको गठन विधि विधानले नेपाली सेनाको वर्तमान संरचनामा प्रभाव पारेको हो । (Shah, 2009)।

प्राविधिक सेवामा सांस्कृतिक कारणहरुले गर्दा पनि केही जात/समूहको नेपाली सेनामा ज्यादा र केहीको थोरै प्रतिनिधित्व भएको हो ।

नेपाली सेनाले पछिल्लो समय नेपाली सेनामा भर्नाको दौरान 'अनियमितता' गर्ने विरुद्ध कारबाही प्रक्रिया पनि कडाइका साथ बढाएको थियो (Ghimire, 2018)। यसले गर्दा नेपाली सेनामा योग्यताक्रमका आधारमा सबै समुदाय, वर्गले भर्ना प्रक्रियामा लगायतको विश्वसनीयता स्थापित हुन मद्दत पुगेको कुरो स्पष्ट छ।

सेनाले पेशागत दक्षता कायम राख्न मेरिटोक्रेसीलाई कायम राख्दै विविधतामा पनि ध्यान दिनु जरुरी छ (Huntington 1957)।

\section{निष्कर्ष}

नेपाली सेनाले यसको स्थापना कालदेखि नै समावेशीकरणमा जोड दिदै आएको छ। हालको समावेशीकरणको 'राजनीति' मा आफूलाई निरपेक्ष राख्नै नेपाली सेनाले योग्यताक्रममा आधारित नेपालभित्रका योग्यता पुगेका सम्पूर्ण व्यक्तिलाई वर्ग, जात, लिड्ग, धर्म, क्षेत्रीयता, आर्थिक अवस्था आदिको आधारमा भेदभाव नगरी सकारात्मक विभेदको नीति लिई नेपाली सेनाभित्र सेवा गर्ने वातावरण बनाउन आवश्यता यसले नेपाली सेनाको कार्यदक्षतामा यथेष्ट सुधार भई नेपाली सेना देशभित्र र बाहिर एक सम्मानित संस्थाका रुपमा रहनेछ। साथै नेपाली सेनाले दक्षिण एसियाकै सबैभन्दा पुरानो राष्ट्र राज्य नेपालको सार्वभौमिकता मजबुत बनाउन 'अनावश्यक' दबाब भन्दा पनि जायज समावेशिताको मागलाई उचित सम्बोधन गरी भर्ना, वृक्ति विकास लगायतका अवसरहरुमा ठाउँ दिएमा मात्र नेपाली सेना विश्वकै उत्कृष्ट र विश्वसनीय सेनाको रुपमा आफूलाई कायम गर्न सक्दछ।

सकारात्मक विभेद, आरक्षण, समावेशीकरण प्रकिया नेपाली सेनाको सक्षमता बढाउने तवरले हुनुपई न
कि कसैको अनुचित दबाब, प्रभाव वा प्रायोजनमा। यदि उपयुक्त तवरले समावेशीकरण प्रकियालाई बढाएमा मात्र नेपाली सेनाले प्राप्त गरेको 'सबभन्दा पत्याइएको' (The Asia Foundation, 2017, p. 70) नेपाली राज्यको अड़को साखलाई कायम गर्न सक्छ। विविधतायुक्त सेनाले नै उच्चतम प्रतिफल दिने भएकाले नेपालभित्र भएका सम्पूर्ण वर्ग, जात, क्षेत्र, लिड्ग, समुदाय लगायतलाई नेपाली सेनाले अभ बढ़ी समेटी नेपाली सेनाको दक्षता, क्षमता बढाई नेपाल जस्तो 'सफ्ट स्टेट' को सार्वभौमसत्ता जोगाउनु र सुदृढ गर्न जरुरी छ। त्यसरी नै आरक्षण दिंदा आर्थिक अवस्था हेरेर पछाडि परेकालाई समावेशीकरण गर्ने हिसाबले अँगालिने वास्तविक रुपमा लागु भएमा मात्र नेपाली सेना लगायत नेपाली राज्यका सबै अडुहरु वास्तविक अर्थमा समावेशी हुने देखिन्छ।

\section{सन्दर्भ सामाग्री सूची}

नेपाल कानुन आयोग। राष्ट्रपिता बडामहाराजा श्री $ै$ पृथ्वीनारायण शाहको दिव्य-उपदेश । http://www. lawcommission.gov.np/np/wpcontent/uploads $/ 2021 / 02 / \%$ E0\%A4\%AA \%E0\%A5\%83\%E0 $\%$ A4\%A $\%$ E0\%A $\%$ \% $8 \%$ E0\%A4\%B5\%E0 $\%$ A $5 \% 80 \%$ E0\%A4\%A $8 \%$ E0\%A4\%BE\%E0 $\% \mathrm{~A} 4 \% \mathrm{~B} 0 \% \mathrm{E} 0 \% \mathrm{~A} 4 \% \mathrm{BE} \% \mathrm{E} 0 \% \mathrm{~A} 4 \% \mathrm{AF} \% \mathrm{E}$ 0\%A4\%A3-A4\%B9\%E0\%A4\%95\%E0\%A5$\%$ E $0 \%$ A $4 \%$ A $6 \%$ E $0 \%$ A $4 \%$ B F $\%$ $5 \%$ E $0 \%$ A $5 \% 8$ D \% E $0 \%$ A $4 \%$ A F $89 \%$ E $0 \%$ A $4 \%$ A A $\%$ E $0 \%$ A $4 \%$ $\mathrm{A} 6 \% \mathrm{E} 0 \% \mathrm{~A} 5 \% 87 \% \mathrm{E} 0 \% \mathrm{~A} 4 \% \mathrm{~B} 6$.pdf मा उपलब्ध; ११ पौष २०७७ मा हेरिएको ।

नेपाल सरकार (२०७२) नेपालको संविधान । http://www.lawcommission.gov.np/np/archives /documents $\% \mathrm{e} 0 \% \mathrm{a} 4 \% \mathrm{a} 8 \% \mathrm{e} 0 \% \mathrm{a} 5 \% \quad 87 \% \mathrm{e} 0$ $\%$ a $4 \%$ a $\%$ e $0 \%$ a $4 \%$ be $\%$ e $0 \%$ a $4 \%$ b $2 \%$ e $0 \%$ a $4 \% 95 \%$ e $0 \%$ a $5 \% 8$ b - \% e $0 \%$ a $4 \%$ b $8 \%$ e $2 \% 80 \% 8$ c \% e $0 \%$ a $4 \% 82 \%$ e $0 \%$ a $4 \% \mathrm{~b} 5 \% \mathrm{e} 0 \quad \% \quad$ a4\%bf\%e0\%a4\%a $7 \% \mathrm{e} 0 \%$ $\mathrm{a} 4 \% \mathrm{be} \% \mathrm{e} 0 \% \mathrm{a} 4 \% \mathrm{a} 8$ मा उपलब्ध; १६ पौष २०७७ मा हेरिएको ।

का, दीपेन्द्र (२०७०) सेनामा मथेशी : चुनौतीमा समावेशिता : मधेश अध्ययन, १(२),पृ. १६४-१६६। 
राष्ट्रिय मानव अधिकार आयोग (२०७७) दलित समुदायको मानव अधिकारको अवस्था प्रतिवेदन आ.व.२०७६/०७७, हरिहरभवन, ललितपुर ।

राष्ट्रिय समावेशी आयोग (२०७७) दोस्रो वार्षिक प्रतिवेदन आ. व. २०७६/०७७। पुल्चोक, ललितपुर ।

लोक सेवा आयोग (२०७७)एकसट्ठीऔं वार्षिक प्रतिवेदन (२०७६ श्रावण-२०७७ आषाढ)। काठमाडौं।

शाह, सौभाग्य (२०४७७) कर्णाली : पीडा र मुक्तिका उपाय । हिमाल १०(४), पृ.१२-१४।

(२०६४) 'एकता दिवस' मा विडम्बनापर्ण संयोग। समय माघ ३, पृ. २६-२७।

सिलवाल, पूर्ण (२०७७) नेपालको एकीकरण, समायोजन र राष्ट्रिय एकता । सुरक्षा (A Journal of Security Affairs), १(१), पृ.७४-५ ४ ।

Bhattarai, K.D. (2009, June 15). Nepali Army trashes Madhesis demand for group entry into NA.

The Himalayan Times. Retrieved from: https:// thehimalayantimes.com/opinion/nepali-armytrashes-madhesisae-demand-for-group-entryinto-na/

Budhathoki, A. (2019, July 10). Britain's Nepali Gurkha veterans struggle for justice. The

Diplomat. Retrieved from: https:// thediplomat.com/2019/07/britainsnepali-gurkha-veterans-strugglefor-justice/\#: : text $=$ For $\% 20$ two $\% 20$ centuries $\% 2 \mathrm{C} \% 20$ the $\% 20 \mathrm{UK}$, and $\% 0$ the $\% 20$ Race \%20 Relations\%20Acts.

Central Department of Sociology and Anthropology. (2014). Social inclusion survey 2012:caste,

ethnic and gender dimensions of socio-economic development, governance and social solidarity.

Chand, P. (2020, December 27). Yaspatak Misanbata Pharkiyapachhui (Returned from misson

this time) Retrieved from: https://deshsanchar. com/2020/12/27/455009/

Demographies of Nepal. (2020 December 28). In Wikipedia.

https://en.wikipedia .org/wiki/Demographics_of_ Nepal
Deupala, M. (2019, July 23). Girl Gurkhas. Nepali Times, Retrieved from:

https://www.nepalitimes.com/banner/girlgurkhas/

Economic Times (2020, September 3). SC refuses to entertain plea for permanent commission of

women officers after cut - off date. Retrieved from : https://economictimes.indiatimes.com/news/ defence/sc-refuses-to-entertain-plea-forpermanent-commission-of-women-officersafter-cut-off-date/articleshow/77908337. cms?from $=\mathrm{mdr}$

Executive Order No. 13583, U.S. Office of personnel management: Office of diversity and inclusion (2011). Retrieved from: https://www.opm.gov/policy-dataoversight/diversity-and-inclusion/reports/ governmentwidedistrategicplan.pdf

Explained: Rise of women soldiers around the world.WION. Retrieved from: https://www. wionews.com/opinions-blogs/explained-riseof-women-soldiers-around-the-world-279075

Ghimire, B. (2018, November 29). 173 convicted of bribing for Nepal Army jobs. The Kathmandu Post.Retrieved from: https:// kathmandupost.com/

Ghimire, Y. (2016, September 15). How the Gorkha Regiments may be on Nepal PM's agenda in India. The Indian Express. Retrieved from: https://indianexpress.com/article/world/ world-news/how-the-gorkha-regiments-maybe-on-nepal-pms-agenda-in-india-3032551/

Hasnain, S.A. (2019, April 22). Demand for new caste -, faith- or ethnicity- based regiments for Indian Army not in consonance with policy or national interest. Firstpost. Retrieved from: https://www.firstpost.com/india/demand-fornew-caste-faith-or-ethnicity-based-regimentsfor-indian-army-not-in-consonance-withpolicy-or-national-interest-6494681.html

Huntington, S.P. (1957). The Soldier and the State. Cambridge: Harvard University Press.

International Labour Organization (2018). Workforce diversity and reservation policy in Nepal: a strategic approach to strengthening 
women's voice and visibility in formal employment sector. Geneva, Switzerland: International Labour Organization. Retrieved from: https:/www.ilo.org/wcmsp5/groups/ public/---dgreports/---dcomm/documents/ publication/wcms_616209.pdf

Kamarck, K.N. (2017). Diversity, inclusion, and equal opportunity in the armed services: Background and issues for Congress (CSR Report R44321). Washington, DC: Congressional Research Service.

Languages of Nepal. (2021 February 7). In Wikipedia. https://en.wikipedia.org/wiki/ Languages_of_Nepal

Lim, N., Haddad, A., \& Daugherty, L. (2013), Implementation of the DOD diversity and inclusion strategic plan: A Framework for Change through Acoountability, Santa Monica, CA: Rand.

Lohani-Chase, R.S. (2008). Women and Gender in the Maoist People's War in Nepal: Militarism and Dislocation. PhD Dissertation. New Jersey: ProQuest and State University of New Jersey.

Mahat, K.B. (2011). Final Report on jumli people in civil service: a study of jumla district. Unpublished report submitted to the Social Inclusion Research Fund, Lalitpur.

MacDonald, D.P., \& Park, K.M. (Eds.). (2012), Managing Diversity in the Military: The value of inclusion in a culture of uniformity. Routledge: London.

Maharjan, N. (2020), Corona Sab Byabasthapan garne Nepali senako mahila toli (Nepali Army's women team on dead body management by Covid 19) Retrieved from: https://www. setopati.com/social/224975

Munshi, A. (2018). An Assessment of the transition in employment policies of Indian Army towards gender inclusion (Doctoral thesis, Symbiosis Internationl University, India). Retrieved from http://shodhganga.inflibnet. ac.in:8080/jspui/handle/10603/191620.

. (2019).Impact of HR policies on gender inclusion in Indian Army: an Empirical study.
South Asian Journal of Human Resource Management, 6(1), 9-28.

National Planning Commission. (2018). Nepal's multidimensional poverty Index: Analysis towards action. Retrieved from: https://www. npc.gov.np/images/category/Nepal_MPI.pdf

NATO. (2018). Summary of the national reports of NATO member and partner nations of the NATO committee on gender perspectives. Retrieved from: https://www.nato.int/nato static_fl2014/assets/pdf/2020/7/pdf/2007132018-Summary-NR-to-NCGP. pdf

Nepali Army. (2019, February 5). Women in Nepal Army (Video file). You Tube. https:// www.youtube.com/watch?v=YtwiXJX87yk

Nepali Army. (2019, December 18). Inclusiveness in the Nepali Army. Retrieved from: https:// www.nepalarmy.mil.np/

(2019, December 18).Women in Nepali Army. Retrieved from: https:/www. nepalarmy.mil.np/

. (2020, November 23). The Nepal Army in UN peace support operations. Retrieved from: https://www.nepalarmy.mil.np/page/na_in_un

Pariyar, M. (2020). Caste, military, migration: Nepali Gurkha communities in Britain, Ethnicities 20(3), 608-627. Retrieved from: https://journals.sagepub.com/doi/ pdf/10.1177/1468796819890138

Pfaff-Czarnecka, J. (1997).'Vestiges and visions: Cultural change in the process of nationbuilding in Nepal'. In Nationalism and Ethnicity in a Hindu Kingdom: The Politics of Culture in Contemporary Nepal. David.N. Gellner, Joanna Pfaff-Czarnecka and John Whelpton, eds. 419-470. Amsterdam: Harwood Academic Publishers.

Racovita, M. (2018), Women in State Security Provision in Nepal: Meaningful Participation? : Small arms survey. Retrieved from: https:// www.jstor.org/stable/pdf/resrep17653.pdf?refreqid=excelsior\%3A1a2761418f05dd35f9dcd566a 4 cc4f52

Richardson, R., Resteigne, D., \& Mathias, B. (2014), Perspective on diversity in the military: A comparison between Belgium and the 
Netherlands: International Journal of Social Science Studies, Vol. 2 No. 3,P. P. 38-49.

Saran, S. (2020 December 30), Unfolding crisis in Nepal. The Tribune. Retrieved from: https:// www.tribuneindia.com/news/comment/unfolding-crisis-in-nepal-191159

Shah, S. (2004). A Himalayan red herring? Maoist revolution in the shadow of the legacy Raj. In M. Hutt (ed.), Himalayan 'People's War': Nepal's Maoist Rebellion (pp. 192-224). Retrieved from: https://libcom.org/library/himalayan-red-herring-maoist-revolution-shadow-legacy-raj-saubhagya-shah

. (2009), Sovereign deficit: Fragmented polity, defense dilemma and the battle for civilian Supremacy in Nepal: Contributions to Nepal Studies, 36(2), 169-211.

Sharma, G. (2020 December 1), Nepal's female soldiers break taboos to tackle Covid crisis. Reuters. Retrieved from: https://www.reuters. com/article/health-coronavirus-nepal-women/ nepals-female-soldiers-break-taboos-to-tackle-covid-crisis-idINKBN28B3HT

Shrestha, B. K. (2012). Federalising back to the Baise Chaubise days: An anthropological perspective on ethnicity as the basis for state restructuring in Nepal, Ethnicity and Federalisation in Nepal, Kathmandu: Central Department of Sociology/Anthropology.

Silver. H. (2015). The contexts of social inclusion. DESA Working Paper No. 144. New York: Department of Economic and Social Affairs. Retrieved from: https://www.un.org/esa/desa/ papers/2015/wp144_2015.pdf

Social Inclusion Action Group. (2008). Workforce Diversity in International Agencies in Nepal. Kathmandu: Social Inclusion Action Group. Retrieved from: https://www.academia. edu/34470992/Workforce_Diversity_in_International_Agencies_in_Nepal_Newar_Tarai_Janajati_Madhesi_Dalit_Other_Madhesi_Caste_Groups_Muslim_Others

The Asia Foundatin (2017). A Survey of the Nepali People in 2017. San Francisco, CA: U.S.A. Retrieved from: https://asiafoundation. org/wp-content/uploads/2018/04/Survey-of-
the-Nepali-People-in-2017_revised-752018. pdf

The British Army (n.d.). People diversity and inclusion. Retrieved from: https://www.army. mod.uk/people/work-well/diversity-and-inclusion/

The Kathmandu Post (2014 March 11). 158 women inducted in Nepal Army. Retrieved from: https://kathmandupost.com/valley/2014/03/11/158-women-inducted-to-nepal-army

The Norwegian Defence University College. (2010). Gender and military issues: a categorized research bibliography. Moving Soldiers, 1, Oslo: The Norwegian Defence University College. Retrieved from: file://C:/Users/ citys/Downloads/Genderand MilitaryIssuesintheScandinavianCountries-ACategorizedResearchBibliography2012.pdf

United Nations Resident and Humanitarian Coordinator's Office. (2013). Inclusiveness of the Nepal Army: Why is the Madheshi community under-represented?3 Retrieved from:reliefweb.int/sites/reliefweb.int/files/resources/Field $\% 20$ Bulletin $\% 20$ issue $\% 2052 \% 20$ Inclusiveness $\% 20$ of $\% 20$ the $\% 20 \mathrm{Nepal} \% 20$ Army_\%20\%20why\%20is\%20the\%20Ma.... pdf

U.S. Army. (2020). Army people strategy: Diverstiy, equity, and inclusion annex. Retrieved from:https://www.army.mil/e2/downloads/ rv7/the_army_people_strategy_diversity_equity_and_inclusion_annex_2020_09_01_ signed_final.pdf

Wilen, N. \& Heinecken, L. (2017). Regendering the South African army: Inclusion, reversal and displacement. Gender Work Organ, 1-17, Retrieved from:https:/www.researchgate.net/ profile/Nina_Wilen/publication/324589455 Regendering_the_South_African_army_ Inclusion_reversal_and_displacement/ links/5eaab $\overline{2}$ ee92851c $\bar{b} 267 \overline{6} 6$ e524/Regendering-the-South-African-army-Inclusion-reversal-and-displace ment .pdf

Zivetz, L. (1992). Private enterprise and the state in modern Nepal. London: Oxford University Press. 